\title{
Investigating the Response to Meristem Culture of Four Regional Sweetpotato Varieties in the Western Highlands of Cameroon
}

\author{
Eugene L. Tatah ${ }^{1}$, Christopher T. Chi ${ }^{1}$, Balgah A. Roland ${ }^{1} \&$ Nardine D. Nsaidzeka ${ }^{1}$ \\ ${ }^{1}$ College of Technology, The University of Bamenda, Bambili, Bamenda, Cameroon \\ Correspondence: Eugene L. Tatah, College of Technology, The University of Bamenda, Bambili, Bamenda, \\ Cameroon. E-mail: teugenelendzemo@yahoo.com
}

Received: July 18, 2019 Accepted: August 2, 2019 Online Published: August 22, 2019

doi:10.5539/sar.v8n4p1 URL: https://doi.org/10.5539/sar.v8n4p1

\begin{abstract}
In the Western highlands of Cameroon where sweetpotato (Ipomoea batatas L.) is an inevitable staple crop during the dry season, farmers cherish local which are presently under the risk of extinction due to accumulation of pest and diseases. Guaranteeing sustainable Sweetpotato production in this region therefore requires providing farmers with disease free planting materials such as tissue cultures. This study was conducted to investigate the feasibility of introducing disease free planting materials from meristem culture of EX-KOLB, EX-GUZANG2, EX-WIDIKUM3 and EX-NKAMBE1 which are four regional sweetpotato varieties common in the Western highlands of Cameroon. Test tubes containing growing media and meristems from each of the varieties were labeled and laid out in a completely randomized experimental design (CRD) with four replications and four treatments. Data on the number of sprouted meristems, number of rooted meristems, number of meristems contaminated, number of meristems that died, average heights of developed plants, average number of nodes on the developed plants, and average number of leaves on the developed plants was collected over a period of 8 weeks at 2 weeks interval. Meristems from all the landraces sprouted in the media used and the differences in the mean number of sprouted meristem between the landraces were significant $(\mathrm{P}<0.05)$. EX-GUZANG2 gave the highest mean of sprouted meristems of (2.75) and EX-WIDIKUM3 the lowest (0.75). According to ANOVA response of meristems from the four landraces to the media used differed significantly only in number sprouted, number of contaminated and number dead meristems as well as number of nodes $(\mathrm{P}<0.05)$. No significant differences were observed with number of contaminated and dead meristems, rooting as well plant height, number of leaves and nodes formed $(\mathrm{P}>0.05)$. This genotype-dependent response to media used for in vitro regeneration by plants has been observed by many studies. However meristems from EX-GUZANG2 and EX-KOLB showed greater positive respond to this media and merit further studies for the purpose of this experiment.
\end{abstract}

Keywords: sweet potato, landrace, In-vitro, meristem culture, Bambui, Cameroon

\section{Introduction}

Sweetpotato (Ipomoea batatas L.) is a member of the plant family Convolvulaceae in the genus Ipomoea It is considered the most important species of economic importance within the genus (Titus et al., 2010; Scott et al., $2000 \mathrm{a} / \mathrm{b}$ ). Studies shows the sub-tropical regions of Central America as the center of domestication from where sweetpotato was spread to the rest of the world particularly by European travelers (Zhang et al., 2004). Today sweet potato is cultivated in more than 100 countries most of them in the tropics and subtropics. Among important crops in the global context, sweetpotato ranks seventh from the viewpoint of total production after wheat, rice, maize, potato, barley and cassava (Kays, 2005).

Nutritionally, sweetpotato is an important staple in many parts of the tropics and subtropics. Sweetpotato is presently one of the crops being biologically fortified with micronutrients to help improve proven deficiencies particularly in children and women across the developing countries found mainly in the tropics and subtropics. Research shows that besides sweetpotato's food usage, it is an important feed as well as reliable renewable raw material for fuel grade ethanol, biogas, biodegradable plastics, a myriad of bioproducts and value added chemicals which are highly demanded by the rapidly emerging global bioeconomy. Hence to achieve both food and income security which is central to the sustainable development goals (Wambugu 2003; Clark et al., 2012), 
commercializing sweetpotato cultivation is worth considering. In Cameroon the national programs concerned with food self-sufficiency has been helping in introducing and improving suitable sweetpotato cultivars to meet the demands of farmers. However, due to lack of extension services many introduced varieties remain unattended to and farmers cultivate them for so long that they often falsely considered them as indigenous crop and are often referred to as the "local" or "traditional" sweetpotato (Andrade et al., 2009). These local varieties are cherish by farmers (Gibson et al., 2009) due to their widely accepted taste, high adaptability to local conditions and in particular their well developed resistance to endemic pest and diseases. Vegetative technique by vine cutting is the only method used by these farmers to propagate their plants. Recent advancement in industrial agriculture and the eminent climate change impacts are negatively affecting plants particularly local varieties which are mainly managed by informally educated poor farmers. The plants are exposed to serious genetic erosion and possible extinction. With vegetative technique as the only means to propagate these landraces, they are mostly neglected to new pest and diseases especially accumulation of viruses which has been internationally observed to cause a phenomenon referred to as 'cultivar decline' whereby the yield and/or quality of a sweetpotato cultivar gradually declines in a broadly accumulative manner over the years (Clark et al., 2002). These and other adverse effects accruing from climate change and increasing global pollution are serious constraints to securing ample planting material which is vital for sustainable cultivation of sweetpotato for livelihood enhancement of smallholder farmers. The need to make available alternative of propagation techniques that conserve threatened local sweetpotato varieties and ensure ample healthy planting material is crucial for sustainable sweetpotato industry establishment (Zawedde et al., 2014).

Internationally, in-situ (conservation on farm) and ex-situ (conservation under protection)techniques are at the disposal of farmers, but in-situ techniques preferred by smallholder farmers because they are easier to carryout have not solve the problem of accumulation of dreaded cryptic pathogens such as viruses. The risk of accidentally introducing such quarantine pests along with the host plant material remains high (ISPM 11, 2013). To date, ex-situ techniques which include in-vitro methods remain the best option for conserving disease free but true to type local varieties. Based on knowledge that sweetpotato tips shows the least virus accumulations among vine cuttings, meristem-tip culture has been demonstrated and recommended as an effective in vitro technique for eliminating viruses for disease free sweetpotato germplasm exchange(Dugassa \& Feyissa 2011; Alam et al., 2012). The objective of this research was to investigate the response to meristem culture of EX-KOLB, EX-GUZANG2, EX-WIDIKUM3 and EX-NKAMBE1 which are four regional sweetpotato varieties common in the Western Highlands of Cameroon for possible introduction as planting material in the near future.

\section{Materials and Methods}

\subsection{Description of Study Site}

This study was carried out at the tissue culture laboratory of one of Cameroon government's Institute of Agricultural Research for Development (IRAD), located at Bambui in the Western Highland Agro-ecological zone situated at altitudes ranging between $1,100 \mathrm{~m}$ and $2,000 \mathrm{~m}$ above sea level (ASL). This is the coolest part of Cameroon with a distinct rainy season lasting 8 months and a dry season lasting 4months. The region is characterized by unimodial rainfall distribution in the range $1500-2500 \mathrm{~mm}$ per annum. The prevailing average temperatures is $19.3^{\circ} \mathrm{C}$ and the relative humidity rises above $80 \%$ during the rainy season but drops drastically during the dry season with significant constraints on food crop production. Sweetpotato by virtue of its renowned ability to produce reliable yield under marginal conditions is a well-established staple food resource during the dry season all over this region.

\subsection{Selection of Sweetpotato Landraces}

The root and tuber division of IRAD Bambui has a well conserved sweetpotato germplasm collection among which the varieties EX-NKAMBE1, EX-GUZANG2, EX-WIDIKUM3, and EX-KOLB were selected for this study on the basis of their renowned high yielding potentials under marginal conditions across the Western Highlands of Cameroon. Sample vines from these plants were harvested for meristem culture experiments in the laboratory. 


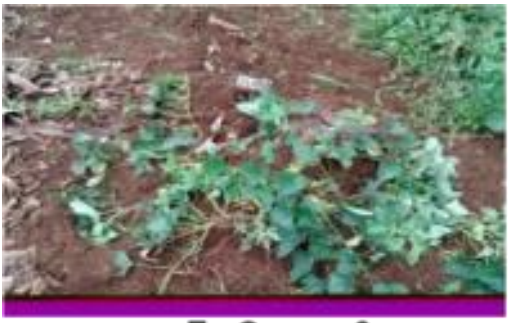

Ex-Guzang2

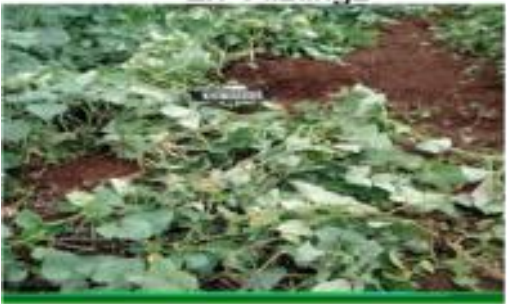

Ex-Kolb

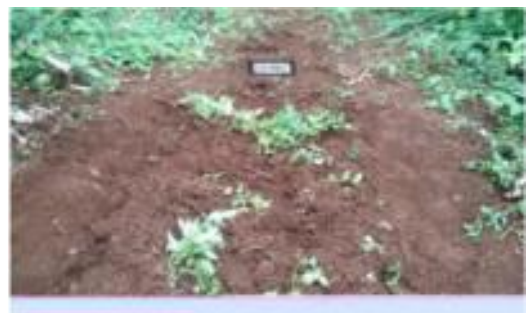

Ex-Widikum3

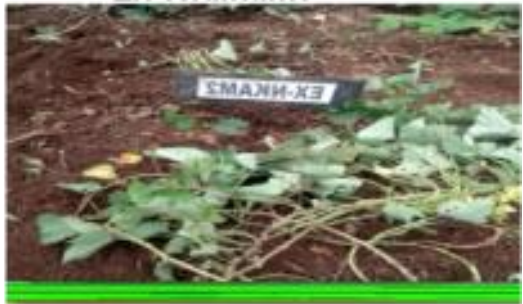

Ex-Nkambe 2

Figure 1. Sweet potato (Ipomoea batatas L.) Landraces at IRAD germplasm farm

Equipments used in laboratory included forceps for holding the shoot explant to a fixed position, Dissecting blades and syringe needle tips for removing leaves and some leaf primordial that covered the meristem, distiller for preparing distilled water, Murashige and Skoog powder, Gibberellic acid, kinetin Myo- inositol and sugar for growth media preparation, $70 \%$ alcohol, la croix and Tween 20 solutions for sterilization, refrigerator for storing prepared stock solutions, cotton, papers, hypodermal needles, scalpels, , pressure pot for sterilization purposes, $\mathrm{pH}$ meter for measuring media acidity and alkalinity, pipettes, beakers, test tubes, stir plate and magnetic stirrer, binocular microscope and microwave. Tools used for meristem culture such as, test tubes, forceps, cotton, papers, hypodermal needles, scalpels, were sterilized at $121^{\circ} \mathrm{C}$ and $103.4 \mathrm{KPa}$ for 20 minutes.

\subsection{Preparation of Stock Solutions, Primary Culture Media, Meristem Sterilization \& Experimental Design}

In all the experiments, a full strength Murashige and Skoog (MS) stock solution was used as growing media for primary shoot induction as well as for shoot multiplication. Nutrient Stocks solutions labeled as solution I, II, III and IV were prepared according to prescriptions of Murashige and Skoog (MS) (1962) where each nutrient was allowed to completely dissolve before the addition of the next. The final volume of each stock solution was adjusted by adding sterile distilled water after which all were stored in a refrigerator at temperature of $8^{\circ} \mathrm{C}$. Separate solutions of Gibberellic acid at concentration of $0.1 \mathrm{mgml}^{-1}$ and kinetin at concentration of $1 \mathrm{mgml}^{-1}$ were also prepared and added as growth regulators. 
Table 1. Nutrient stocks type, their composition and amounts used in preparing the stock solutions

\begin{tabular}{lll}
\hline Nutrient stock Type & Composition & Amounts used \\
\hline Macro elements ( stock I)/l & Ammonium nitrate $\left(\mathrm{NH}_{4} \mathrm{NO}_{3}\right)$ & $16.5 \mathrm{~g}$ \\
& Potassium nitrate $\left(\mathrm{KNO}_{3}\right)$ & $19.0 \mathrm{~g}$ \\
& Anhydrous calcium chloride $\left(\mathrm{CaCl}_{2} \cdot 2 \mathrm{H}_{2} \mathrm{O}\right)$ & $4.4 \mathrm{~g}$ \\
& Anhydrous magnesium sulphate $\left(\mathrm{MgSO}_{4} \cdot 7 \mathrm{H}_{2} \mathrm{O}\right)$ & $3.7 \mathrm{~g}$ \\
& Potassium hydrogen phosphate $\left(\mathrm{KH}_{2} \mathrm{PO}_{4}\right)$ & $1.7 \mathrm{~g}$ \\
Micro elements ( stock II)/l & Manganese sulphate $\left(\mathrm{MnSO}_{4} \cdot \mathrm{H}_{2} \mathrm{O}\right)$ & $446 \mathrm{mg}$ \\
& Boric acid $\left(\mathrm{H}_{2} \mathrm{BO}_{3}\right)$ & $124 \mathrm{mg}$ \\
& Zinc sulphate $\left(\mathrm{ZnSO}_{4} \cdot 7 \mathrm{H}_{2} \mathrm{O}\right)$ & $172 \mathrm{mg}$ \\
& Potassium iodide $\left(\mathrm{KI}^{2}\right)$ & $16.6 \mathrm{mg}$ \\
& Sodium molybdenum $\left(\mathrm{NaMoO}_{4}\right)$ & $5 \mathrm{mg}$ \\
& Cupric sulphate $\left(\mathrm{CuSO}_{4} \cdot 5 \mathrm{H}_{2} \mathrm{O}\right)$ & $0.5 \mathrm{mg}$ \\
Iron stock ( Stock III)/100ml & Cobalt chloride $\left(\mathrm{CoCl}_{2} 6 \mathrm{H}_{2} \mathrm{O}\right)$ & $0.5 \mathrm{mg}$ \\
& Disodiumethylenediaminetetraacetate $\left(* \mathrm{Na}_{2} \mathrm{EDTA}\right)$ & $0.75 \mathrm{~g}$ \\
Vitamins (stock IV) $500 \mathrm{ml} l$ & $0.55 \mathrm{~g}$ \\
& Iron sulphate $\left(* \mathrm{FeSO}_{4} \cdot 7 \mathrm{H}_{2} \mathrm{O}\right)$ & $20 \mathrm{mg}$ \\
& Thymine hydrochloride & $100 \mathrm{mg}$ \\
& Glycine & $25 \mathrm{mg}$ \\
Kinetin $1 \mathrm{mg} / \mathrm{ml}$ & Nicotinic acid & $25 \mathrm{mg}$ \\
$\mathrm{GA}{ }_{3} 0.1 \mathrm{mg} / \mathrm{ml}$ & Pyridoxine hydrochloride & $0.1 \mathrm{~g}$ \\
& Kinetin & $100 \mathrm{mg}$ \\
\hline
\end{tabular}

\subsubsection{Preparation of Primary Media for Shoot Initiation}

Media for primary shoot initiation was prepared according to Alams protocol (2013) where the required amount of each Stock solution, Myo-inositol, stock solutions of growth regulators and 30g of sugar were measured and added successively to a $1000 \mathrm{ml}$ beaker whose contents were continuously stirred over a magnetic plate (Table 2). Sterilized distilled water was added to the final solution to reach $1000 \mathrm{ml}$ volume. Using a potentiometer, the $\mathrm{pH}$ of the final solution was adjusted to 5.8 using standard solutions. This made the final nutrient media for growing the meristems. Two milliliters of the final nutrient media was pipetted into ninety (90) sterilized test tubes which were covered with sterilized cotton and autoclaved at $121^{\circ} \mathrm{C}$ and $103.4 \mathrm{KPa}$ for 15 mintes. The test tubes were then allowed to cool overnight.
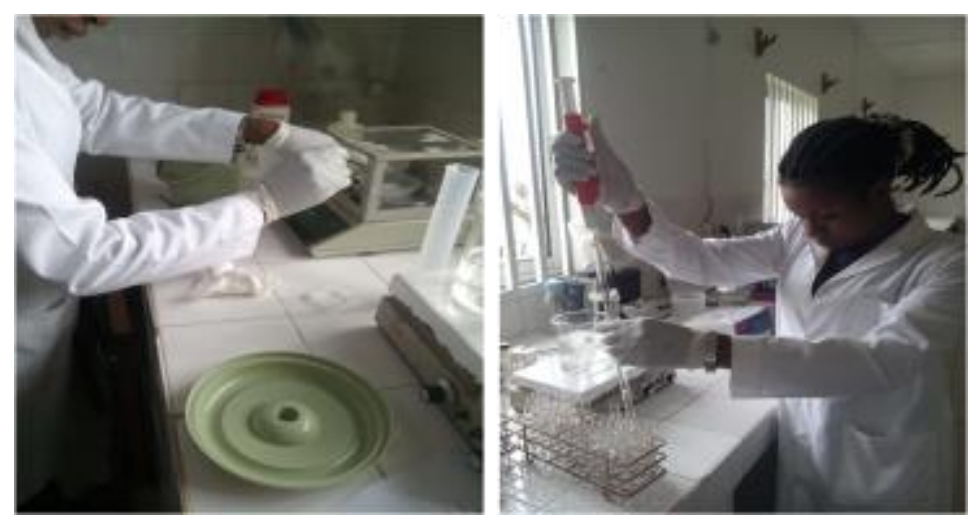

Figure 2. Nutrient media preparation and distribution 
Table 2. Materials and quantity in $1000 \mathrm{ml}$ for media preparation for primary shoot induction

\begin{tabular}{ll}
\hline Material & Quantity in 1000ml \\
\hline Stock I & $100 \mathrm{ml}$ \\
Stock II & $10 \mathrm{ml}$ \\
Stock III Iron + EDTA & $5 \mathrm{ml}$ \\
Stock IV Vitamins & $10 \mathrm{ml}$ \\
Sucrose & $30 \mathrm{~g}$ \\
Myo inositol & $0.1 \mathrm{~g}$ \\
Gibberellic acid GA ${ }_{3}(0.1 \mathrm{mg} / \mathrm{ml})$ & $5 \mathrm{ml}$ \\
Kinetin $(1 \mathrm{mg} / \mathrm{ml})$ & $24 \mathrm{ml}$ \\
pH & $5.8 \pm 0.2$ \\
\hline
\end{tabular}

\subsubsection{Experimental Design}

The ninety (90) test tubes containing the media were labeled and laid out in a completely randomized design (CRD) with four replications and four treatments. The four treatments were basically meristems from each of the four sweetpotato (Ipomoea batatas L.) varieties. By replicating the four treatments four times, a total of 16 experimental units were obtained. Each experimental unit consisted of 5 test tubes with their appropriate growing media and experimental meristem tissues.

\subsubsection{Preparation \& Sterilization of Meristems}

From the experience that plant meristems are rich in phenol amines which inhibits viruses (Kassahun et al., 2014), meristem culture has been recommended for use to eliminate viruses in sweetpotato (Panta et al., 2006). Based on this, meristems for this experiment were taken from sweetpotato vines tips of $2-3 \mathrm{~cm}$ long healthy looking vine stems containing at least six buds that were judged visually and harvested from each of the four sweetpotato varieties. Leaves were then removed from the vine stems.
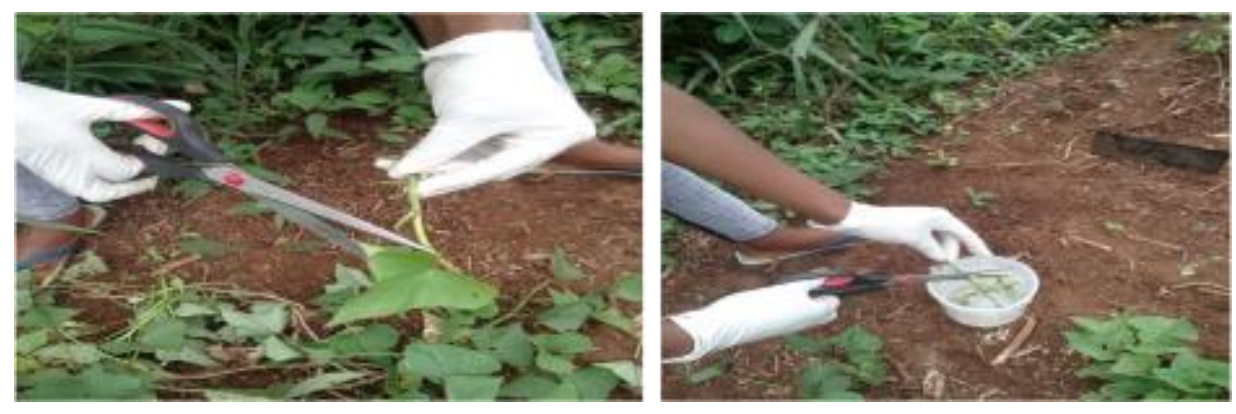

Figure 3. Harvesting and preparing sweetpotato (Ipomoea batatas L.) vine stems for lab meristem excision

The leafless vine stems were taken to the tissue culture laboratory where they were submerged in labelled beakers containing tap water to prevent them from dehydrating.

In the laboratory, the collected vines were cut into stem sections containing at least three buds and were rinsed with running tap water to remove all surface debris. Surface sterilization was done using the method of Binchang et al, (2012), by which the rinsed vines were dipped for 10 minutes into appropriately labelled beakers containing a solution of 30\% "la croix"(a solution of sodium hypochlorite used locally in Cameroon as a a disinfectant and 20 dropsl $^{-1}$ of nonionic surfactants called Tween20 (a polyoxyethylene sorbitol ester). After 10 minutes, the solution was decanted and the vines were now immersed into a $70 \%$ ethanol solution for 30 seconds and finally transferred to a laminar flow chamber to ensure aseptic conditions.

Inside the laminar flow chamber, the $70 \%$ alcohol solution was replaced with a $2.5 \%$ solution of 'la croix' containing 20 drops of Tween and allowed 20 for 15 minutes. Then, the la croix solution was decanted and the vines rinsed four times with sterile distilled water to remove the distillate. The vines were kept immersed in the sterilized distilled water ready for excision of the meristems. 

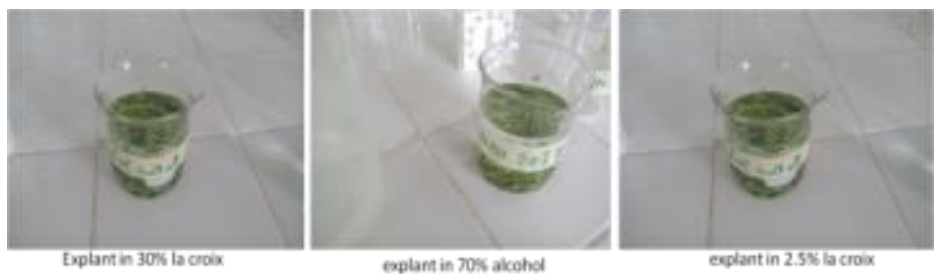

Figure 4. Sample prepared Sweetpotato vines in different concentrations of sterilizing solutions

Meristems from the different landraces were excised under an alcohol-swapped binocular stereo microscope (Magnification 40X), using sterile forceps, dissecting blades and syringe needle tips. Sterile forceps were used to hold the shoot to a fixed position while dissecting blades and syringe needle tips were used to remove leaves and some leaf primordial that covered the meristem.
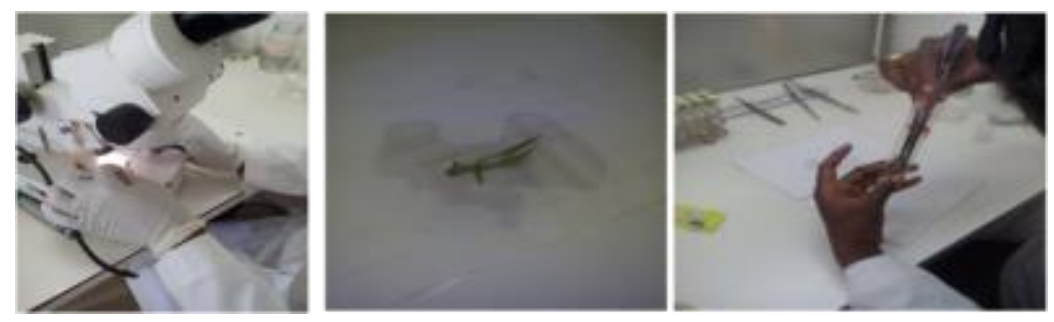

Figure 5. Excising and transferring meristems into test tubes under a binocular stereo microscope

The meristems were excised such that each had part of the leaf premodium attached. The excised meristems were then placed on the culture media (prepared a day before) contained in test tubes and transferred into the growth chamber with a temperature of $25^{\circ} \mathrm{C}$ and a photoperiod of 16 hours/day and allow to grow for 4 weeks during which data for shoot initiation (number of meristem sprouting) was collected once every two weeks.

\subsection{Preparation of Shoot Multiplication Media}

After 4 weeks, sprouted meristems from each of the four sweet potato land races were transferred into a shoot multiplication media. This media was prepared following same procedures as with shoot initiation media except the addition of slightly higher kinetin concentration and the addition of hormones and sucrose. The $\mathrm{pH}$ of the media was also adjusted to 5.8 and agar was added to give it a semi solid consistency. The resulting media was heated in the microwave for 10 minutes to aid dissolution and then distributed into test tubes ready for further cultivation of sprouted meristems.

Table 3. Materials and quantities for media preparation for shoot multiplication induction

\begin{tabular}{ll}
\hline Material & Quantity in 1000ml \\
\hline Stock I & $100 \mathrm{ml}$ \\
Stock II & $10 \mathrm{ml}$ \\
Stock III Iron + EDTA & $5 \mathrm{ml}$ \\
Stock IV Vitamins & $10 \mathrm{ml}$ \\
Sucrose & $30 \mathrm{~g}$ \\
Myo inositol & $0.1 \mathrm{~g}$ \\
Gibberellic acid GA $3(0.1 \mathrm{mg} / \mathrm{ml})$ & $5 \mathrm{ml}$ \\
Kinetin $(1 \mathrm{mg} / \mathrm{ml})$ & $30 \mathrm{ml}$ \\
Agar & $12 \mathrm{~g}$ \\
Ph & $5.8 \pm 0.2$ \\
\hline
\end{tabular}

Sprouted meristems were then placed on the media in the test tubes and subjected to conditions of $25^{\circ} \mathrm{C}$ and 16/8_h (light/dark photo period) for 4 weeks. During this period, data on the development (contamination of sprouts, dead meristems, formation of callus, formation of roots, average heights of plants developed and their corresponding average number of nodes and leaves formed) of meristem sprouts was collected once every two weeks. All data was collected by manual counting with the aid of the microscope and magnifying lenses. 


\section{Data Analysis and Results}

Data collected was analyzed using Microsoft excel 2007, the Statistical Package for Social Science (SPSS) version 17.0 and the analysis of variance (ANOVA) was used to compare the treatments. Means significantly different were separated using the Least Significant Difference (LSD) at probability level 0.05.

\subsection{Results on Shoot Initiation Studies Based on Number of Sprouted Meristem}

On average, EX-GUZANG2 recorded the highest number (2.75) of sprouted meristems and EX-WIDIKUM3 the least $(0.75)$ as can be inferred from Fig6 below. The mean number of sprouted meristems differed significantly between the four landraces as revealed by ANOVA $(\mathrm{P}<0.05)$.

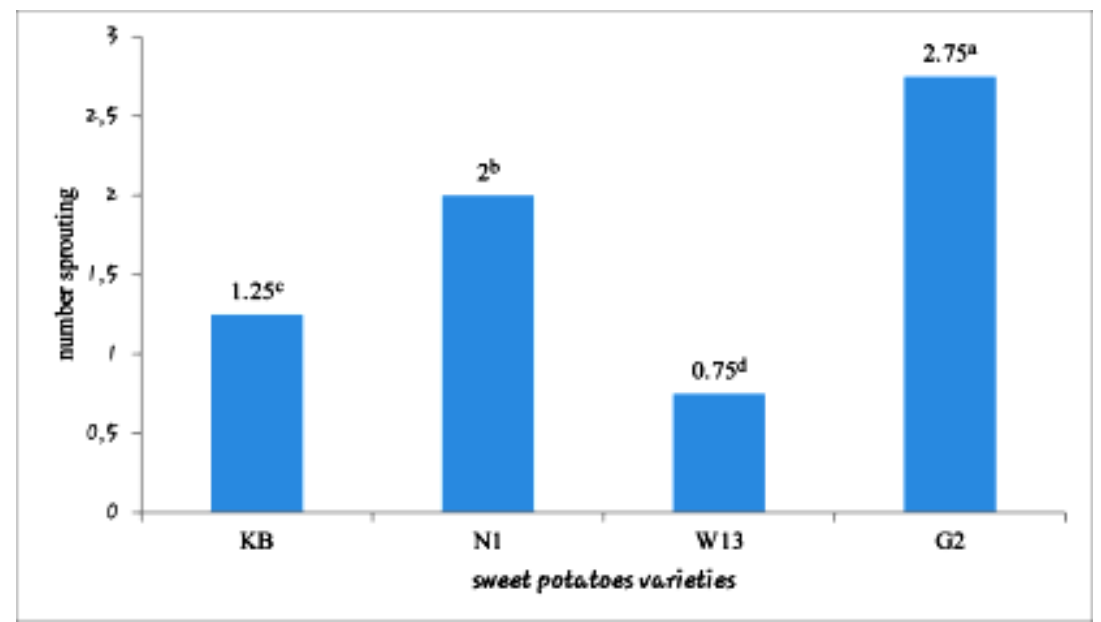

Figure 6. Results on primary shoot initiation studies based on number of sprouted meristems

$\mathrm{KB}=\mathrm{EX}-\mathrm{KOLB} ; \mathrm{N} 1=\mathrm{EX}-\mathrm{NKAMBE} 1 ; \mathrm{W} 13=\mathrm{EX}-\mathrm{WIDIKUM} 3 \mathrm{G} 2=\mathrm{EX}-\mathrm{GUZANG} 2$

\subsection{Results from Shoot Multiplication Studies}

Shoot multiplication studies considered number of meristems that became contaminated, number of meristems that died, number of roots formed, number of callus formed, heights of plants developed and their corresponding number of nodes and leaves formed

\subsubsection{Average Number Rooted Meristems Sprouts}

Fig7 below shows that only meristem sprouts from EX-KOLB were observed to form roots with average of 0.75 number of roots formed. Meristems sprouts from EX-NKAMBE1, EX-WIDIKUM3 and EX-GUZANG2 surprisingly did not form roots in the media used.

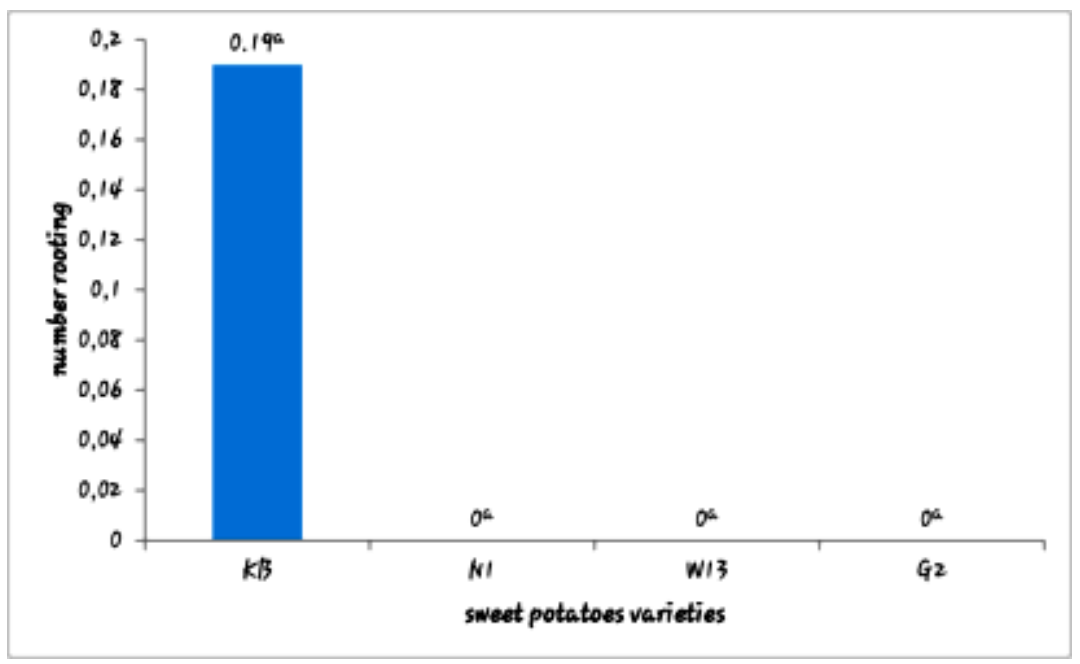

Figure 7. Average number rooted meristem sprouts3.2.2 Average number of contaminated meristems

KB= EX-KOLB; N1= EX-NKAMBE1; W13= EX-WIDIKUM3; G2= EX-GUZANG2. 
Meristem sprouts from all the sweet potato landraces became contaminated (Fig8) with significant differences between the four sweetpotato varieties. EX-WIDIKUM3 recorded the highest (4.69) and EX-GUZANG2 the least (2.13) average number of contaminated meristems.

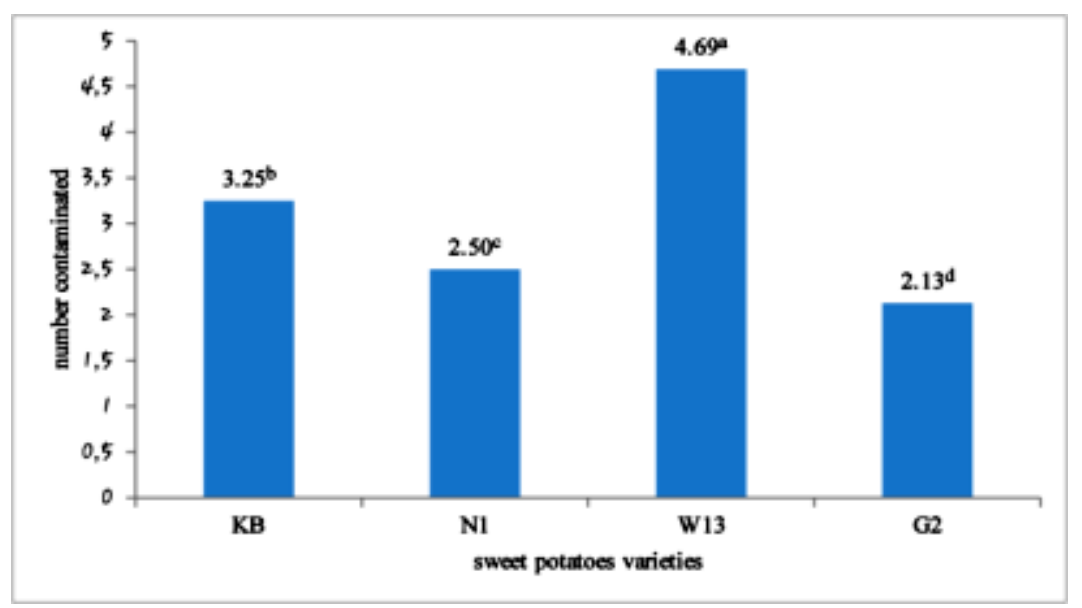

Figure 8. Average number of contaminated meristems

$\mathrm{KB}=\mathrm{EX}-\mathrm{KOLB} ; \mathrm{N} 1=\mathrm{EX}-\mathrm{NKAMBE} 1 ; \mathrm{W} 13=\mathrm{EX}-\mathrm{WIDIKUM} 3 ; \mathrm{G} 2=$ EX-GUZANG2.

\subsubsection{Average Number of Dead Meristems}

Figure 9 shows meristems to have died only with varieties EX-KOLB 2 EX-NKAMBE1 and EX-GUZANG2. The differences in the average number of dead meristems among these three varieties were significant with EX-NKAMBE1 recording the highest (0.75) number of dead meristems. Meristems of EX- WIDIKUM3 did not record any dead at all.

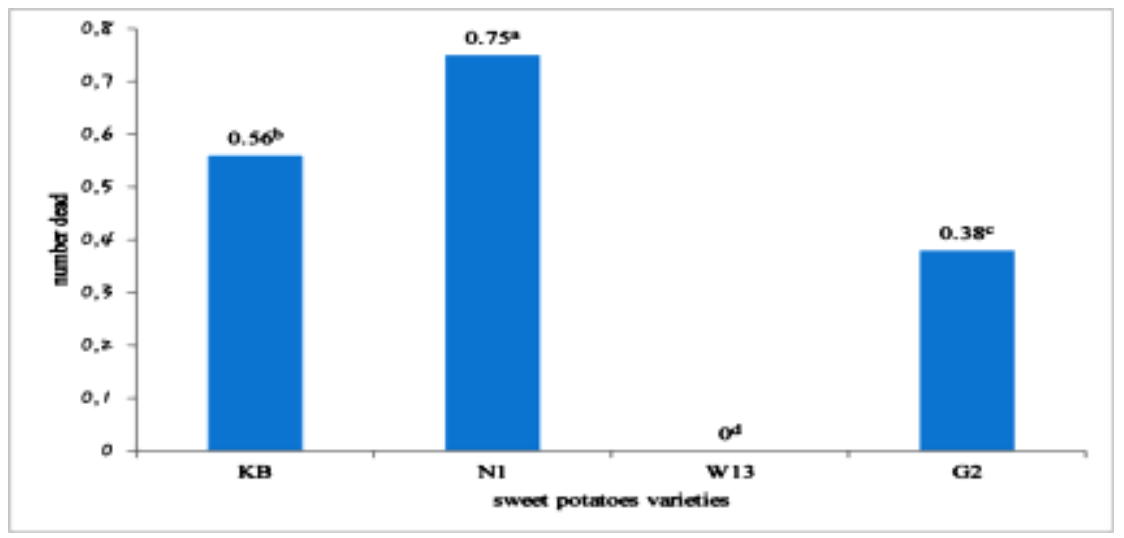

Figure 9. Average number of dead meristems

KB= EX-KOLB; N1= EX-NKAMBE1; W13= EX-WIDIKUM3; G2= EX-GUZANG2

\subsubsection{Average Heights of Plant Developed from Meristems Sprouts}

Average heights of all plants developed from meristems of the four different varieties increased throughout the eight weeks of study with significant differences in the increases observed between the varieties $(\mathrm{P}>0.05)$. Fig 10 shows EX-KOLB to have developed the longest average plant height $(16.34 \mathrm{~mm})$ and EX-WIDIKUM3 the shortest $(1.59 \mathrm{~mm})$. 


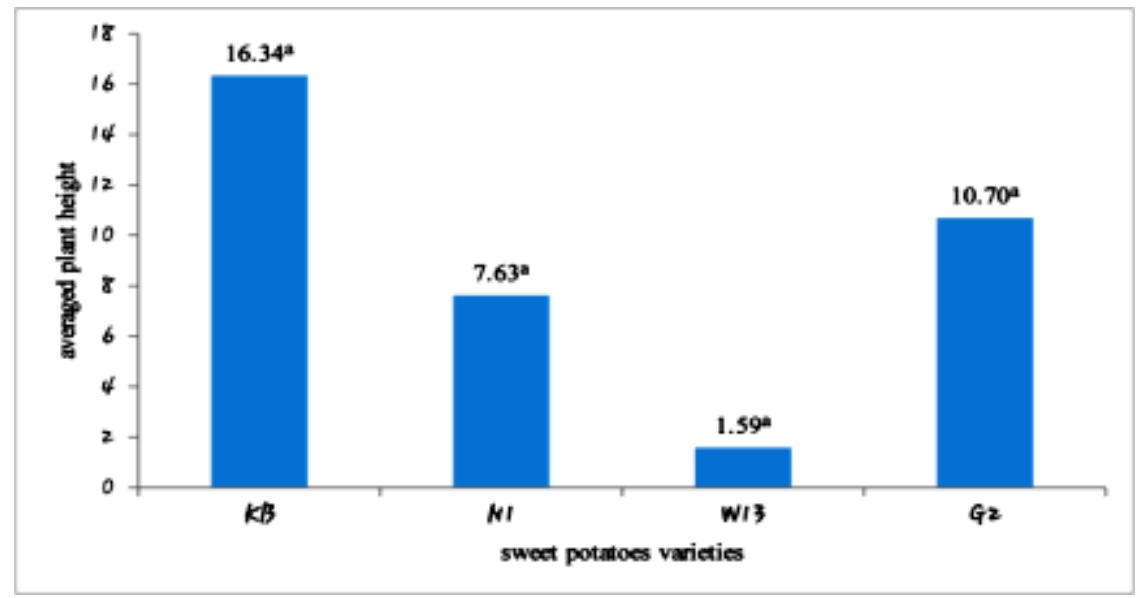

Figure 10. Average heights of plants developed from meristem sprouts

KB= EX-KOLB; N1= EX-NKAMBE1; W13= EX-WIDIKUM3; G2= EX-GUZANG2

\subsubsection{Average Number of Nodes on Plant Developed from Meristems Sprouts}

All meristems sprouts from each of the four sweetpotato varieties form significantly different number of nodes. EX-KOLB produced the highest number (2.78) of nodes while EX-WIDIKUM3 produced the least (0.33) as shown in Fig11 below.

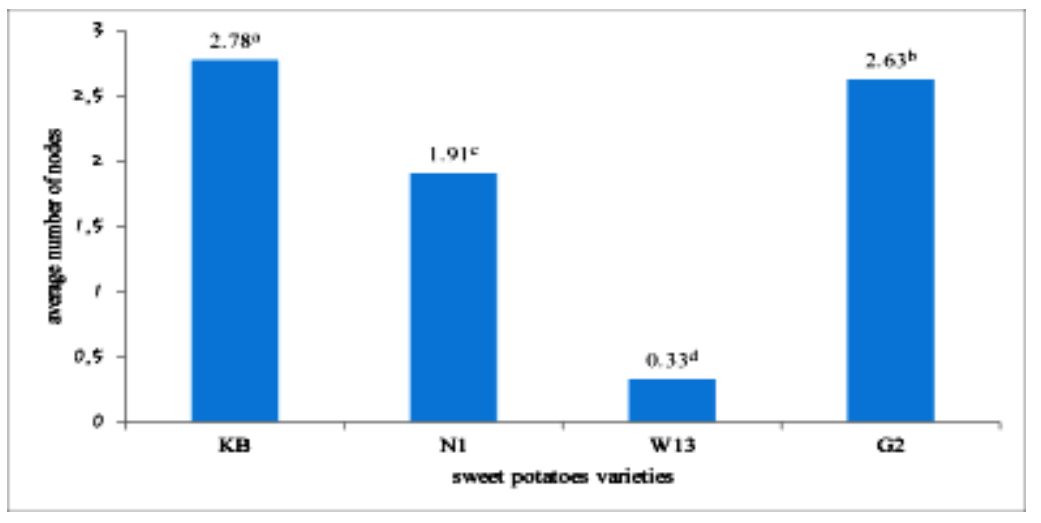

Figure 11. Average number of nodes on plants developed from meristem sprouts

$\mathrm{KB}=\mathrm{EX}-\mathrm{KOLB} ; \mathrm{N} 1=\mathrm{EX}-\mathrm{NKAMBE} 1 ; \mathrm{W} 13=\mathrm{EX}-\mathrm{WIDIKUM} 3 ; \mathrm{G} 2=\mathrm{EX}-\mathrm{GUZANG} 2$

\subsubsection{Average Number of Leaves on Plant Developed from Meristems Sprouts}

Figure 12 shows leaves to have been formed only by plants developed from meristems of EX-KOLB, EX-NKAMBE1 and EX-GUZANG2. The average number of leaves formed differed significantly among the three varieties with EX-KOLB producing the highest (3.5) and EX-NKAMBE1 the lowest (1.91). Plants developed from meristems of EX-WIDIKUM3 failed to produce leaves. 


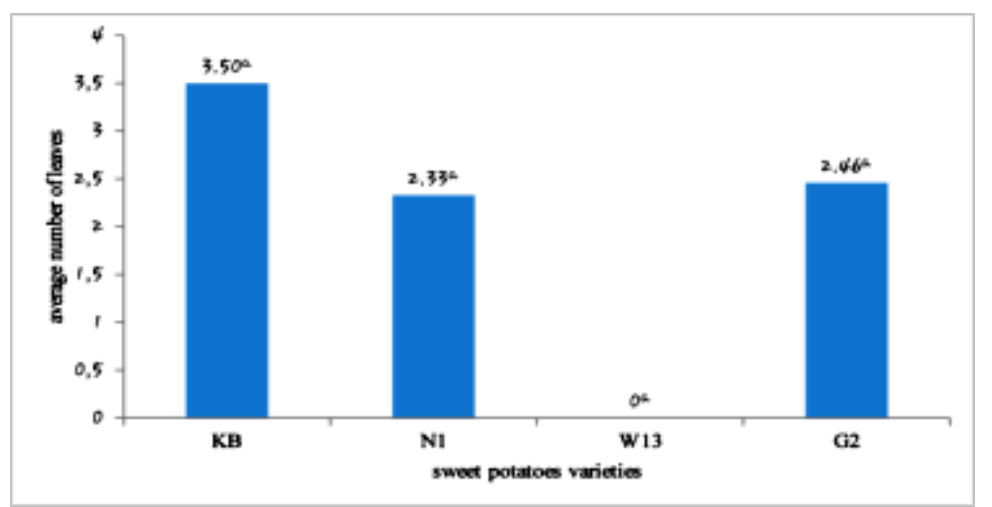

Figure 12. Average number of leaves on plants developed from meristem sprouts

$\mathrm{KB}=\mathrm{EX}-\mathrm{KOLB} ; \mathrm{N} 1=\mathrm{EX}-\mathrm{NKAMBE} 1$; W13= EX-WIDIKUM3; G2= EX-GUZANG2

\subsubsection{Number Meristems Forming Callus}

Meristems from all the four land races formed callus with EX-GUZANG2 forming the highest average number (1.13) of callus and EX-WIDIKUM3 the least (0.13) (fig 13). Significant differences in the average number of meristems forming callus between the landraces were recorded .

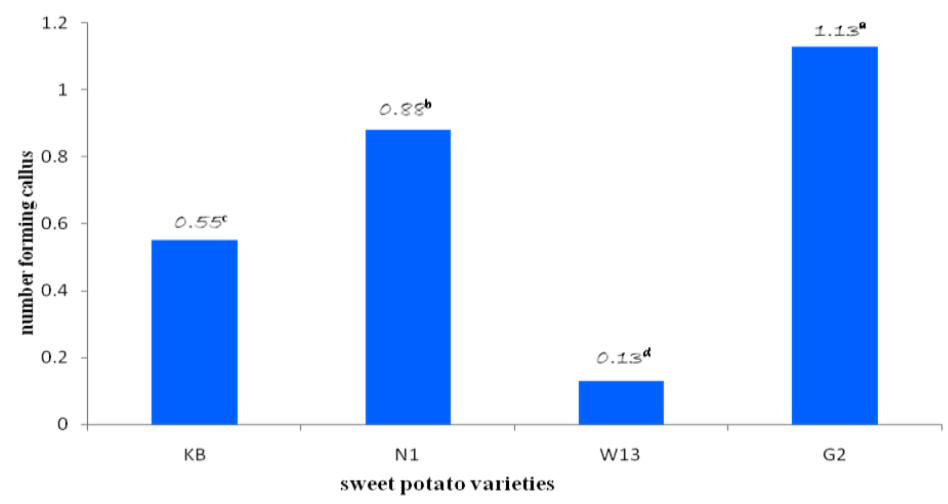

Figure 13. Number of meristem forming callus

$\mathrm{KB}=\mathrm{EX}-\mathrm{KOLB} ; \mathrm{N} 1=\mathrm{EX}-\mathrm{NKAMBE} 1$; W13= EX-WIDIKUM3; G2= EX-GUZANG2

\section{Discussions}

Several studies on sweetpotato plant regeneration by invitro organogenesis (i.e. using explants derived from various organs, such as stems, petioles, leaves and roots) have described sweetpotato plant as recalcitrant (not very responsive) to this effect. The frequency of regenerating new plants has generally been observed to be very low and the response to in vitro regeneration has equally been observed to vary from genotype to genotype (González et al., 2008; Dessai et al., 1995; Ogero, 2009). Since all meristems from the four different varieties used in this study were fed the same nutrient solution, the observed significant differences in the average number of sprouted meristems can best be attributed to genotype effects. This genotype-dependent response to in vitro regeneration methods is a call for research into developing novel or modified invitro regeneration procedures for each desirable genotype (Monica et al., 2009).

Ramdan et al., 2014; Kahn et al., 2015; Nakasha et al., 2016) reported that callus cultures in invitro culture do not usually develop shoots in the absence of growth promoting hormones. This study appears to question this report given the observation that Ex-GUZANG produces the highest number of calluses but failed to form roots despite the addition of growth promoting hormones in the media used.

Meristem contamination has constantly been reported as a major constraint to the development of plant regeneration invitro techniques (Enjalric et al., 1988; Birmeta, 2004). In This study, EX-WIDIKIM that produced the highest number of contaminated meristems, had the worst performance of all the parameters measured except 
for the fact that it recorded no dead meristems among the four varieties. The high rate of contamination may well have been the cause of this poor performance.

A good plant height is required by plantlets to enable easy splicing into nodal cuttings. Higher number of nodes is beneficial for multiplication of the plant during nodal culture. Nodes are points of leaf formation with number of nodes proportionately determining number of leaves. Prolific leaf formation is a welcome factor during meristem culture. Leaves contain chlorophyll which is essential in converting light energy to chemical energy hence a good leaf system is crucial for successful acclimatization of plantlets. Plantlets with well-structured leaves are photosynthetically efficient, a factor which enhances their speed of adaptation to the natural conditions during acclimatization. A good root system is essential for successful acclimatization of the plantlets and subsequent growth in the field since roots facilitate the absorption of nutrients from the soil (Xiansong, 2010). The degrees of formation of these organs are known to vary from genotype to genotype. With the exception of EX-WIDIKUM3 that failed to form leaves, meristems of all the rest of the landraces formed all the organs required of a healthy plant. Comparing all the four sweet potato land races, EX-KOLB's ability to significantly produce higher number of nodes indicates good regeneration efficiency and hence a promising candidate for the purpose intended.

Alam et al. (2010) observed shoot initiation between the $6^{\text {th }}$ and the $10^{\text {th }}$ day and concluded that if after two weeks of culture, sweet potato meristems fail to sprout in liquid media, they will never do. In agreement with this conclusion, cultured meristems from all the four land races used in this research sprouted from the $6^{\text {th }}$ to the $14^{\text {th }}$ day after which no further sprouting could be observed.

The observation that meristems from all the sweetpotato varieties sprouted in the media used, indicates that the protocol used in the experiments is suitable for the four regional sweet potato varieties. From the result obtained, EX-KOLB had the highest respond in the MS media as indicated by its ability to produce highest number of meristem sprouts, form roots, produce tallest plants with highest number of nodes and hence leaves. EX-WIDIKUM recorded poorest performance and need to be further investigated. Based on the above findings, the following recommendations can be made to researchers in Cameroon western highland:

Priority should be given to EX-KOLB, followed by EX-GUZANG2 and EX-NKAMBEEX-WIDIKUM3 need to be further investigated. May be a new protocol should used.. Sweetpotato plant from which ex-plants for meristem culture are to be collected, should be grown in pots in the screen house to reduce high infestation and further contamination. "La croix" and Tween20 as components of the sterilizing solution should be further checked on their effectiveness.

\section{References}

Andrade, M., Barker, I., Cole, D., Dapaah, H., Elliott, H., Fuentes, S., ... Thiele, G. (2009). Unleashing the potential of sweetpotato in Sub-Saharan Africa: Current challenges and way forward. International Potato Center (CIP), Lima, Peru. pp. 197. https://doi.org/10.4160/0256874820091

Clark, C., Valverde, R., Fuentes, S., Salazar, L., \& Moyer, J. (2002). Research for improved management of sweetpotato pests and diseases: cultivar decline. Acta Hort, 583, 103-112. https://doi.org/10.17660/ActaHortic.2002.583.11

Dessai, A. P., Gosukonda, R. M., Blay, E., Dumenyo, C. K., Medina-Boliva, R. F., \& Prakash, C. S. (1995). Plant regeneration of sweet potato (Ipomoea batatas L.) from leaf explants in vitro using a two-stage protocol. Scientia Horticulturae, 62(4), 217-224. https://doi.org/10.1016/0304-4238(95)00767-N

Enjalric, F., Carron, M. P., \& Lardet, L. (1988). Contamination of Primary Cultures in Tropical Areas: The Case of Hevea Brasiliensis. In: Bacterial and Bacteria-like Contaminants of Plant Tissue Cultures Ishs Acta Horticulturae. pp. 225. https://doi.org/10.17660/ActaHortic.1988.225.6

Geleta, D., \& Tileye, F. (2011). In vitro production of virus-free sweetpotato (Ipomoea batatas) by meristem culture and thermotherapy. Ethiop. J. Sci., 34(1), 17-28.

González, R. G., Sánchez, D. S., Guerra, Z. Z., Campos, J. M., Quesada, A. L., Valdivia, M. R., ... Caligari, P. D. S. (2008). Eficient regeneration and Agrobacterium tumefaciens mediated transformation of recalcitrant sweet potato (Ipomoea batatas L.) cultivars. Asia Pacific Journal of Molecular Biology and Biotechnology, 16(2), 25-33.

Hall, M. R., \& Phatak, S. C. (1993). Sweetpotato [Ipomoea batatas (L.) Lam.]. Genetic Improvement of Vegetable Crops, 693-708. https://doi.org/10.1016/B978-0-08-040826-2.50051-5

Iftekhar, A., Shamima, A. S., Mst. Kamrun, N., Md. Jahangir, A., Mohammad, A., \& Mohammad, F. A. (2012). 
Elimination and detection of viruses in meristem-derived plantlets of sweetpotato as a low-cost option toward commercialization. 3 Biotech, 3(2), 153-164. https://doi.org/10.1007/s13205-012-0080-6

ISPM 11. (2013). Pest risk analysis for quarantine pests. Rome, IPPC, FAO.

Jaafar, J. N., Uma, R. S., Nurashikin, K., \& Kumara, S. M. (2016). Induction, Subculture Cycle, and Regeneration of Callus in Safed Musli (Chlorophytum borivilianum) using Different Types of Phytohormones. Pharmacogn Mag., 12(Suppl 4), S460-S464. https://doi.org/10.4103/0973-1296.191457

Jeyakumar, J. J., \& Vivekanandan, L. (2015). Optimization of conditions for callus induction and indirect organogenesis of Cucumis anguria L. Asian J. Plant Sci. Res., 5(11), 53-6.

Monica, S., Pecota, K. V., Yencho, C. G., Allen, G., \& Sosinski, B. (2009). Rapid shoot regeneration in industrial high starch sweet potato (Ipomoea batatas L.) Genotypes. Plant Cell, Tissue and Organ Culture, 97, 109-117. https://doi.org/10.1007/s11240-009-9504-3

Murashige, T., \& Skoog, F. (1962). A revised medium for rapid growth and bioassays with tobacco tissue culture. Physiol. Plant, 15, 473-497. https://doi.org/10.1111/j.1399-3054.1962.tb08052.x

Nadra, K., Maqsood, A., Ishfaq, H., Nadeem, A., Shaghef, E., \& Muhammad, A. (2015). Optimizing the concentrations of plant growth regulators for in vitro shoot cultures, callus induction and shoot regeneration from calluses of grapes. J. Int. Sci. Vigne Vin, 49, 37-45. https://doi.org/10.20870/oeno-one.2015.49.1.95

Ogero, K. O. (2012). Low cost tissue culture of selected Cassava (Manihot esculanta) and Sweet potato (Ipomoea batatas) varieties. M.Sc.thesis, Kenyatta University, Kenya. pp. 59-67.

Pathleen, T., Janet, L., Herman, A., Ardon, I., Ronnie, P., \& Gregory, R. (2010). Sweet Potato Technical Manual, Caribbean Agricultural Research and Development Institute (CARDI).

Ramdan, R., Handaji, N., Beyahia, H., \& Ibriz, M. (2015). Influence of growth regulators on callus induction from embryos of five citrus rootstocks. Journal of Applied Biosciences, 73, 5959-5965.

Scott, G. J., Best, R., Rosegrant, M., \& Bokanga, M. (2000a). Roots and tubers in the global food system: A vision statement for the year 2020. International Potato Center, Lima, Peru, pp. 111.

Scott, G. J., Best, R., Rosegrant, M., \& Bokanga, M. (2000b). Roots and tubers for the 21 st century. Trends, projections, and policy options. Food, agriculture, and the environment, Discussion paper 31. International Food Policy Research Institute and Centro Internacuional de la Papa, pp. 64.

Serap, K. A., \& Bengi, B. E. (2015). Callus Induction and Adventitious Shoot Regeneration of Centaurea zeybekii Wagenitz: Endangered Endemic Plant. Nevşehir Bilim ve Teknoloji Dergisi Cilt, 4(2), 1-8. http://dx.doi.org/10.17100/nevbiltek.210944

Traynor, M. (2005). Sweetpotato production guide for the top end. Information Booklet IB1. Department of primary Industry, Fisheries, and Mines. Crops, Forestry and Horticulture Division. Northern Territory Government, Darwin, NT, Australia

Xiansong, Y. (2010). Rapid production of virus-free plantlets by shoot tip culture in vitro of purple-coloured sweet potato (Ipomoea batatas (L) Lam.). Pakistan Journal of Biology, 42(3), 2069-2075.

Zhang, Z., \& Corke, H. (2001). Trypsin Inhibitor Activity in Vegetative Tissue of Sweet Potato Plants and its Response to Heat Treatment. Journal of the Science of Food and Agriculture, 81, 1358-1363. https://doi.org/10.1002/jsfa.945

\section{Copyrights}

Copyright for this article is retained by the author(s), with first publication rights granted to the journal.

This is an open-access article distributed under the terms and conditions of the Creative Commons Attribution license (http://creativecommons.org/licenses/by/3.0/). 